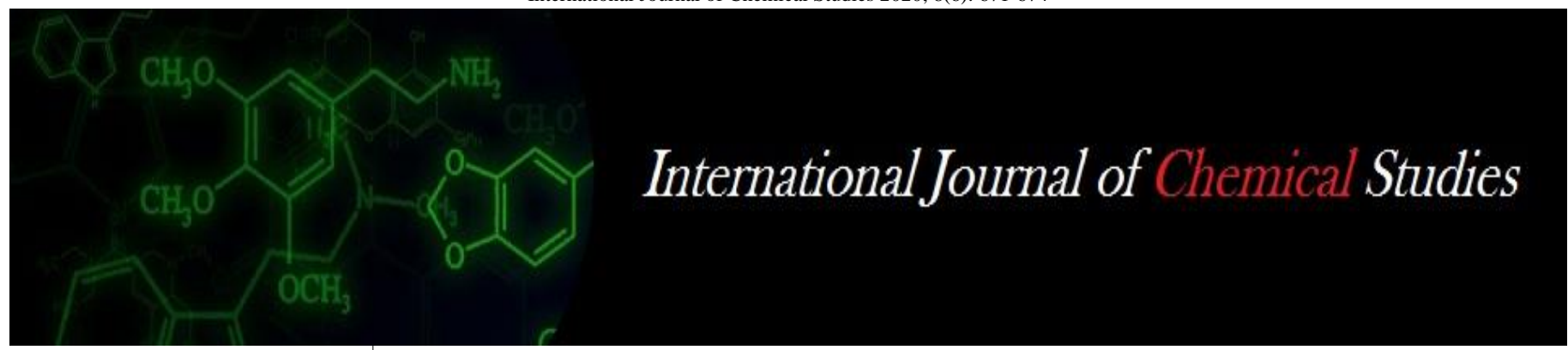

P-ISSN: 2349-8528

E-ISSN: 2321-4902

www.chemijournal.com

IJCS 2020; 8(6): 671-674

(C) 2020 IJCS

Received: 15-08-2020

Accepted: 30-09-2020

Renu Choudhary

Ph.D., (Ag.) Scholar,

Department of Entomology,

College of Agriculture, Swami

Keshwanand Rajasthan

Agricultural University, Bikaner,

Rajasthan, India

\section{HL Deshwal}

Professor and Head, Department of Entomology, College of

Agriculture, Swami Keshwanand

Rajasthan Agricultural

University, Bikaner, Rajasthan,

India

\section{Bishana Ram}

M.Sc. (Ag) Student, Department of Entomology, College of

Agriculture, Swami Keshwanand

Rajasthan Agricultural

University, Bikaner, Rajasthan,

India
Corresponding Author:

Renu Choudhary

Ph.D. (Ag.) Scholar, Department of Entomology, College of

Agriculture, Swami Keshwanand Rajasthan Agricultural

University, Bikaner, Rajasthan, India

\section{Seasonal incidence of $\boldsymbol{H}$. coriandari on fennel and their correlation with biotic and abiotic factors}

\author{
Renu Choudhary, HL Deshwal and Bishana Ram
}

DOI: https://doi.org/10.22271/chemi.2020.v8.i6j.10847

\begin{abstract}
Seasonal incidence of aphid, Hyadaphis coriandari on fennel and their correlation with biotic and abiotic factors were studied at Research Farm, College of Agriculture, SKRAU, Bikaner during two consecutive years i.e., Rabi, 2016-17 and 2017-18. The infestation of H. coriandari commenced in the second week of Feb ( $\left.7^{\text {th }} \mathrm{SMW}\right)$ and remained active throughout the crop season i.e. upto first week of April during both the years. The population of $H$. coriandari attained to its peak in last week of February/first week of March i.e. $9^{\text {th }}$ SMW during both the years. After the peak population, the population of $H$. coriandari started to decline and reached to low level in the $13^{\text {th }}$ SMW near maturity of the crop during both the years. Simultaneously the occurrence of predator, C. septempunctata coincides with the population of aphids during both the years. Maximum temperature had significant negative correlation and minimum temperature had non significant negative correlation with aphid population during 2016-17 where as maximum and minimum temperature had non significant negative correlation with aphid population during 2017-18. Relative humidity morning and C. septempunctata had significant positive correlation with aphid population during both the years. Whereas, relative humidity evening and rainfall had non significant positive correlation with aphid population during both the years (2016-17 and 2017-18).
\end{abstract}

Keywords: Fennel, seasonal incidence, aphid, Hyadaphis coriandari, C. septempunctata

\section{Introduction}

Fennel Foeniculum vulgare (Miller) is an important spice crop of the family Apiaceae, commonly known as 'saunf' and occupy prominent place among spices in India. India is said to be 'Home of spices' The seed of fennel contain $9.5 \%$ protein, $10.0 \%$ fat, $18.5 \%$ crude fiber, $42.3 \%$ carbohydrates, $13.4 \%$ minerals and also rich in vitamins and volatile oil ranged from 2.17 to $2.60 \%$ (Pruthi, 1976). The leaves are reported to have diuretic properties, whereas, the root are purgative (El-Awadi and Hassan, 2011; Singh and singh, 1996) ${ }^{[3,14]}$. Among the different pests aphid, $H$. coriandari causes maximum damage to the fennel crop. Both nymph and adult cause damage by sucking the cell sap from tender stem, leaves, inflorescence and developing grains and secreting honey dew. Due to their fast multiplication within few days, aphid cover the entire surface of apical shoots and as a result of continuous feeding by such a large population yellowing, curling and subsequent drying of leaves takes place resulting in poor and shriveled seed formation.

\section{Material and Methods}

Present investigation on seasonal incidence of aphid, H. coriandari were conducted on fennel (variety RF-125) at the Research farm College of Agriculture, Swami Keshwanand Rajasthan Agricultural University, Bikaner during Rabi 2016-17 and 2017-18. The crop was sown $24^{\text {th }}$ October 2016 and $30^{\text {th }}$ October 2017 in $100 \mathrm{~m}^{2}(10 \mathrm{x} 10 \mathrm{~m})$ area maintained row to row and plant to plant distance of 40 and $20 \mathrm{~cm}$ respectively. The recommended package of practices was followed for raising the crop. The population of aphid was recorded from twenty randomly selected and tagged plants. The visits of the experimental field was made early in the morning at weekly interval to observe the occurrence of aphid. As soon as the aphid population appeared, the numbers were counted from three umbles (lower, middle and upper) of each plants. Simultaneously the data of predator $C$. septempunctata was recorded. The data on weather parameters was obtained from meteorological observatory Agriculture Research Station, Swami Keshwanand Rajasthan Agricultural University, Bikaner. 
The correlation coefficient was worked out between aphid population with biotic $C$. septempunctata and abiotic factors (temperature, relative humidity and rainfall).

\section{Result and Discussion}

It was observed that the infestation of fennel aphid, $H$. coriandari commenced in the second week of Feb. which was $7^{\text {th }}$ SMW and remained active throughout the crop season i.e. upto first week of April during 2016-17 and 2017-2018 (table 1 and 2). The population of aphid ranged between 12.50 to 71.8 and 6.1 to 54.0 aphid/plant during 2016-17 and 2017-18, respectively. Initially, the population of $H$. coriandari was $19.10 \& 15.0$ per plant during 2016-17 and 2017-18, respectively. The population of $H$. coriandari increased gradually week after week and attained to its peak in last week of February/first week of march i.e. $9^{\text {th }}$ SMW (71.8 aphids/plant) and (54.0 aphids/plant) during 2016-17 and 2017-2018, respectively. After reaching the peak, the population of aphid started to decline and reached to low level in the $13^{\text {th }}$ SMW near maturity of the crop during both the year. These results are in agreement with those of Kalra et al., (2006) ${ }^{[5]}$, Patel et al., (2011) ${ }^{[10]}$, Purti et al., (2017) ${ }^{[12]}$ and Kanjiya et al., (2018) ${ }^{[6]}$ who reported the appearance of $H$. coriandari on fennel in different weeks of February. However, Hirpara (2000) ${ }^{[4]}$, Meena et al., (2009) ${ }^{[8]}$, Pareek et al., (2013) [9] and Swami et al., (2018) [15] reported the incidence of aphid started in the month of January. Contrary to the present findings Kumar and Sagar (1994) ${ }^{[7]}$ recorded $H$. coriandari population during the month of December on coriander. In the present investigation the aphid population increased gradually and reached at its peak in $4^{\text {th }}$ week of February/ $1^{\text {st }}$ week of March ( $9^{\text {th }}$ SMW) during 2016-17 and 2017-18. The present findings are in agreement with those of Hirpara (2000) ${ }^{[4]}$, Aslam et al., (2007) ${ }^{[2]}$, Patel et al., (2011) ${ }^{[10]}$, Purti et al., (2017) ${ }^{[12]}$, Pareek et al., (2013) ${ }^{[9]}$ and Swami et al., (2018) ${ }^{[15]}$ who recorded peak incidence of aphid in the $4^{\text {th }}$ week of February/ $1^{\text {st }}$ week of March.

Simultaneously the occurrence of predator, C. septempunctata coincides with the population of aphids during both the years. The population of $C$. septempunctata ranged between 0.30 to 6.30 and 0.0 to 5.5/plant during 2016-17 \& 2017-18, respectively. Initially, the population of $C$. septempunctata was $5.70 \& 3.0$ per plant in $\left(7^{\text {th }}\right.$ SMW) during $2016-17 \&$ 2017-18, respectively. The population of $C$. septempunctata increased gradually week after week and reached to its peak in first week of March i.e. $9^{\text {th }}$ SMW (6.30/plant) and (5.5/plant) during 2016-17 \& 2017-18, respectively. Swami et al., (2018) ${ }^{[15]}$ observed peak activity of $C$. septumpuctata with the peak infestation of aphid on coriander similarly Kanjiya et al., (2018) ${ }^{[6]}$ recoded higher population of $C$. septumpuctata during $4^{\text {th }}$ week of January to $3^{\text {rd }}$ week of March. However, Purti et al., (2017) ${ }^{[12]}$ observed highest population of coccinellids in the $2^{\text {nd }}$ week of March support the present findings.

Table 1: Seasonal incidence of $H$. coriandari on fennel during Rabi, 2016-17

\begin{tabular}{|c|c|c|c|c|c|c|c|}
\hline \multirow{2}{*}{ SMW* } & \multicolumn{2}{|c|}{ Temperature $\left({ }^{\circ} \mathbf{C}\right)$} & \multicolumn{2}{c|}{ Relative Humidity (\%) } & \multirow{2}{*}{ Total Rainfall (mm.) } & Aphid population/plant & $\begin{array}{c}\text { Cocinellid } \\
\text { population/plant }\end{array}$ \\
\cline { 2 - 5 } & Max. & Min. & Morning & Evening & & 19.10 & 5.70 \\
\hline 7 & 30 & 10 & 71.7 & 23.3 & 0 & 40.00 & 5.10 \\
\hline 8 & 30.2 & 10.6 & 63.9 & 18.6 & 0 & 71.80 & 7.30 \\
\hline 9 & 30.6 & 13 & 68.3 & 21.7 & 0 & 55.70 & 2.10 \\
\hline 10 & 30 & 11.9 & 66.3 & 19.3 & 0.8 & 38.00 & 1.20 \\
\hline 11 & 30.7 & 12.4 & 63 & 23 & 0 & 22.80 & 0.70 \\
\hline 12 & 36.3 & 18.4 & 57.6 & 21.9 & 0 & 12.50 & 0.30 \\
\hline 13 & 41.1 & 22.5 & 41.1 & 18 & 0 & & \\
\hline
\end{tabular}

*SMW-Standard meteorological weeks

Table 2: Seasonal incidence of H. coriandari on fennel during Rabi, 2017-18

\begin{tabular}{|c|c|c|c|c|c|c|c|}
\hline \multirow{2}{*}{ SMW } & \multicolumn{6}{|c|}{ Temperature $\left({ }^{\circ} \mathbf{C}\right)$} & \multicolumn{2}{c|}{ Relative Humidity (\%) } & \multirow{2}{*}{ Total Rainfall (mm.) } & Aphid population/plant Coccinellid population/ plant \\
\hline & Max. & Min. & Morning & Evening & & 15 & 3.0 \\
\hline 7 & 28.1 & 9.3 & 82 & 33.1 & 0 & 38 & 5.1 \\
\hline 8 & 32.6 & 13.7 & 73.9 & 30.4 & 0 & 54 & 5.5 \\
\hline 9 & 32.8 & 15.4 & 69.7 & 28 & 0.6 & 25.8 & 5.3 \\
\hline 10 & 34 & 14.2 & 61.3 & 20.4 & 0 & 20 & 1.2 \\
\hline 11 & 35 & 16.9 & 55.6 & 17.7 & 0.8 & 6.1 & 1.0 \\
\hline 12 & 33.6 & 16.4 & 58.6 & 23.1 & 0 & 0 & 0.0 \\
\hline 13 & 40.7 & 19.5 & 35.9 & 12 & 0 & & \\
\hline
\end{tabular}

*SMW-Standard meteorological weeks

\section{Correlation of $\boldsymbol{H}$. coriandari with biotic and abiotic factors} The correlation between aphid population and abiotic factors viz., maximum \& minimum temperature, morning \& evening relative humidity and rainfall was worked out during present investigation indicated that maximum temperature exhibited significant negative correlation during 2016-17 however it was non significant negative correlation in 2017-18 (table 3). Singh et al., (2007) reported significant negative correlation with maximum temperature however, Meena et al., (2009) ${ }^{[8]}$ observed significant positive correlation with atmospheric temperature. Minimum temperature exhibited non-significant negative correlation during both the years i.e. 2016-17 \& 2017-18. The results are in agreement with those of Hirpara (2000) ${ }^{[4]}$ Ansari et al., (2007) ${ }^{[1]}$, Purti et al., (2017) ${ }^{[12]}$ and
Swami et al. (2018) ${ }^{[15]}$ reported non significant correlation of minimum temperature with aphid population. Morning relative humidity showed significant positive correlation with aphid population in the present investigation. The results of the present findings are in agreement with those of Purti et al., (2017) ${ }^{[12]}$ who observed significant positive correlation of morning relative humidity with aphid population. In the present findings evening relative humidity showed nonsignificant positive correlation with aphid population. Singh et al., (2007) [13], Purti et al., (2017) ${ }^{[12]}$ and Swami et al., (2018) [15] observed non-significant positive correlation between evening relative humidity and aphid populations. In the present investigation rainfall showed non-significant positive correlation with aphid population. The results are in 
agreement with those of Swami et al., (2018) ${ }^{[15]}$ who reported non-significant positive correlation between rain fall and aphid population. A significant positive correlation during 2016-17 and 2017-18 was observed between the population of C. septempunctata and aphid on fennel (table 3). Patel et al., (2011) ${ }^{[10]}$, Swami et al., (2018) ${ }^{[15]}$ and Kanjiya et al., (2018) [6] depicted significant positive correlation of coccinellids with aphid population on coriander and fennel crop. However, Meena et al., (2009) [8] reported significant negative correlation between adult coccinellids as well as grubs with aphid population.

The maximum temperature has significantly negative ( $\mathrm{r}=$ 0.620) correlation and minimum temperature has nonsignificantly negative $(\mathrm{r}=-0.487)$ correlation with aphid population while morning relative humidity has significantly positive $(\mathrm{r}=0.551)$ correlation and evening relative humidity has non-significantly positive $(r=0.026)$ correlation with aphid population and rainfall has non-significant positive $(r=0.387)$ correlation during 2016-17. During 2017-18 maximum and minimum temperature had non-significant negative $(r=-0.321$ \& $r=-0.196)$ correlation with aphid population, whereas morning relative humidity has significantly positive $(r=0.502)$ correlation and evening relative humidity has nonsignificantly positive $(\mathrm{r}=0.497)$ correlation with aphid population and rainfall has non-significant positive $(\mathrm{r}=0.414)$ correlation. Singh et al., (2007) [13] reported significant negative correlation with maximum temperature however, Meena et al., (2009) ${ }^{[8]}$ observed significant positive correlation with atmospheric temperature. Minimum temperature exhibited non-significant negative correlation during both the years i.e. 2016-17 \& 2017-18. The results are in agreement with those of Hirpara (2000) ${ }^{[4]}$ Ansari et al., (2007) ${ }^{[1]}$, Purti et al., (2017) ${ }^{[12]}$, and Swami et al., (2018) ${ }^{[15]}$ reported non significant correlation of minimum temperature with aphid population. Morning relative humidity showed significant positive correlation with aphid population in the present investigation. The results of the present findings are in agreement with those of Purti et al., (2017) who observed significant positive correlation of morning relative humidity with aphid population. In the present findings evening relative humidity showed non-significant positive correlation with aphid population. Singh et al., (2007) ${ }^{[13]}$, Purti et al., (2017) ${ }^{[12]}$ and Swami et al., (2018) ${ }^{[15]}$ observed non-significant positive correlation between evening relative humidity and aphid populations. In the present investigation rainfall showed non-significant positive correlation with aphid population. The results are in agreement with those of Swami et al., (2018) ${ }^{[15]}$ who reported non-significant positive correlation between rain fall and aphid population. Patel et al., (2011) ${ }^{[10]}$, Swami et al., (2018) ${ }^{[15]}$ and Kanjiya et al., (2018) ${ }^{[6]}$ depicted significant positive correlation of coccinellids with aphid population on coriander and fennel crop. However, Meena et al., (2009) [8] reported significant negative correlation between adult coccinellids as well as grubs with aphid population.

Table 3: Correlation of $H$. coriandari with biotic and abiotic factors during Rabi, 2016-17 and 2017-18

\begin{tabular}{|c|c|c|c|}
\hline S. No. & Biotic/abiotic factors & Correlation coefficient (2016-17) & Correlation coefficient (2017-18) \\
\hline 1 & Maximum temperature & $-0.620^{*}$ & -0.321 \\
\hline 2 & Minimum temperature & -0.487 & -0.196 \\
\hline 3 & Relative humidity Morning & $0.551^{*}$ & $0.502^{*}$ \\
\hline 4 & Relative humidity Evening & 0.026 & 0.497 \\
\hline 5 & Rainfall (mm) & 0.387 & 0.414 \\
\hline 6 & C. septempunctata & $0.530^{*}$ & $0.839^{*}$ \\
\hline
\end{tabular}

\section{References}

1. Ansari MS, Hussain B, Qazi NA. Influence of abiotic environment on the population dynamics of mustard aphid, Lipaphis erysimi (Kalt.) On Brassica Germplasm. Journal of Biological Sciences 2007;7:993-996.

2. Aslam M, Razaq M, Ahmad F, Mirza YH. Population abundance of aphid (Brevicoryne brassicaeL.) and Lipaphis erysimi (kalt.) on Indian Mustard. African Crop Science Society. African Crop Science Conference Proceeding 2007;8:935-938.

3. El-Awadi ME, Hassan EA. Improving growth and productivity of fennel plant exposed to pendimethalin herbicide: stress-recovery treatments. Journal of Nature and Science 2011;9:97-108.

4. Hirpara KD. Bionomics and control of $H$. coriandari (Das) on fennel. M.Sc. thesis submitted to G.A.U., Junagadh campus 2000.

5. Karla VK. Insect pests of seed spice crops and their management, pp 136-142. In Chhillar B. S., Saini, R. K. and Roshan lal (eds). Emerging trend in economic entomology, Center of advance studies, Department of Entomology, Haryana Agricultural University, Hissar 2006.

6. Kanjiya RR, Shah KD, Talaviya JR, Patil VM, Chudasama K Population dynamics of fennel aphid, Hyadaphis coriandari Das and occurrence of coccinellid predators on aphid in fennel. Journal of Entomology and Zoology Studies 2018;6(6):1150-1152.

7. Kumar N, Sagar P. Seasonal history and host range of coriander aphid. (Hyadaphis coriandari Das). Punjab Agricultural University Research Journal 1994;31(3): 283-284.

8. Meena DK, Swaminathan R, Bhati KK, Jain HK. Population dynamics of coriander aphid and its coccinellid predators. Indian Journal of Applied Entomology 2009;23(1):66-69.

9. Pareek RK, Sharma A, Kumawat KC. Seasonal abundance of insect pests and their major natural enemies in coriander, Coriandrum sativum Linn. Indian Journal of Applied Entomology 2013;27(1):21-26.

10. Patel SA, Patel IS, Patel JK, Patel PS. Seasonal abundance of fennel aphid, Hyadaphis coriandari Das and associated bio-agents in fennel crop. Trends in Bioscience 2011;4(1):116-117.

11. Pruthi HS. Spices and Condiments. National Book Trust, India, New Delhi 1976, 103.

12. Purti, Rinku, Anuradha. Correlation between the incidence of coriander aphids (Hyadaphis coriandari), their natural enemies (coccinellids) and abiotic factors of the environment. Chemical Science Review and Letters, 2017;6(23):1745-1749.

13. Singh R, Singh D, Rao VUM. Effect of abiotic factors on mustard aphid (Lipaphis erysimi kalt.) on Indian 
Brassica. Indian Journal of Agricultural Research, 2007;41(1):67-70.

14. Singh VB, Singh K. Spices. New Age International (P) Ltd., New Delhi 1996, 122-130.

15. Swami D, Jat BL, Dotasara SK. Population dynamics of insect pests of coriander and their correlation with biotic and abiotic factors. Journal of Entomology and Zoology Studies 2018;6(4):460-464. 